\title{
Reduction of the Mortality to the General Surgical Department of General Hospital Valjevo - Serbia
}

\author{
Mira H. Vuković1, Vladan R. Ilić ${ }^{2}$ \\ ${ }^{1}$ Education Center, General Hospital Valjevo, Valjevo, Serbia \\ ${ }^{2}$ Department of Intra-Hospital Infections, General Hospital Valjevo, Valjevo, Serbia
}

\section{SUMMARY}

Introduction: The safety of surgical procedures has emerged as a significant global public health problem.

Aim: In this study, an assessment was made of the mortality in the population of general surgical patients and is proposed to prevent the occurrence of adverse events involving death.

Methods: A study of time series that routinely monitored quality indicators was carried out from January to November 2017, with a special reference to the number of deaths and the total mortality rate at the General Surgery Department GSD, General Hospital Valjevo, Serbia.

Results: Hospitalized patients over 65 years of age and prolonged hospitalization of surgical patients positively correlated with the Total mortality rate at the General Surgery Department . The short stay of patients in the Intensive Care Unit of the General Hospital Valjevo significantly reduced the total mortality rate in patients of the General Surgery Department.

Conclusion: It is necessary to introduce routine monitoring of new quality indicators that are directly related to the clinical procedures that lead to the reduction of the mortality in general surgical patients.

Keywords: mortality rate, quality indicator, general surgery

\section{INTRODUCTION}

The safety of surgical procedures has emerged as a significant global public health problem. Surgical complications take major share in all possible medical injuries and causes of death worldwide. It is estimated that unwanted events in surgical patients range from $3 \%$ to $16 \%$ of all hospitalized patients and that more than half of such events can be prevented [1-4]. Despite the dramatic improvements in the safety of surgical procedures, at least half of the adverse events occur during surgical treatment $[5,6]$. The frequency of major operations is estimated at 187-281 million operations, which is an approximately one operation annually to 25 inhabitants [7]. This is a large and previously unforeseen number of operations with significant implications for public health. While fatalities and complications after 
surgery are difficult to compare with case-bycase because of their diversity, economically developed countries have documented the rate of major complications of all surgical procedures ranging from $3 \%-22 \%$, and the mortality rate ranging from $0.4 \%-0.8 \%[5,6]$. Assuming that the perioperative rate of adverse events is $3 \%$ and the mortality rate is $0.5 \%$, it is estimated that almost seven million surgical patients suffer significant complications every year, of which one million die during or immediately after surgery.

Just as public health interventions and educational projects have dramatically improved maternal and neonatal survival, the efforts made by analogy can improve the safety of surgical procedures and the quality of surgical treatment in general $[8,9]$.

\section{AIM}

In this study, an assessment was made of the mortality in the population of general surgical patients and is proposed to prevent the occurrence of adverse events involving death.

Table 1. Overview of the study included quality indicators

\section{METHODS}

\section{Study Design}

A time series, academic study IV phase, was conducted over routinely monitored quality indicators.

\section{Place of study}

The study was conducted in the General Surgery Department of the General Hospital Valjevo (Valjevo, Serbia). General Hospital Valjevo gravitates to 200,000 inhabitants. In the framework of surgical procedures, the General Surgery Department (without children's surgery) performs operational procedures in the area of: abdominal surgery (colorectal surgery, small intestine surgery, gastroduodenal surgery, hepatobiliary surgery - except for liver resection, herniorphyphy and hernioplasty), vascular surgery an artery that includes abdominal aorta, venous surgery, auxiliary renal procedures, amputation of the extremities), breast surgery and thyroid gland surgery.

\section{Time - period of study}

Appropriate indicators of the quality of surgical healthcare were monitored for eleven months in the period from January to November 2017.

Number of hospitalized patients

Number of deaths

Total mortality rate (\%)

Hospitalized patients under 65 years of age

Number of deaths below 65 years of age

Death rate of less than 65 years of age (\%)

Death rate in the first 48 hours of patients' hospitalization (\%)

Hospitalized patients with 65 or more years of age

Number of deaths at the age of 65 or more

Death rate is equal to or more than 65 years of age (\%)

Number of hospital days

The rate of hospital days per patient

Number of nurse per occupied bed

Number of patients in the Intensive Care Unit

Patients rate in the Intensive Care Unit (\%)

Number of re-admissions in the Intensive Care Unit

Percentage of re-admissions in the Intensive Care Unit (\%)

\section{Variables in the study}

The analysis covered the quality indicators shown in Table 1. The dependent (tested) time series were the number of deaths and the overall surgery mortality rate in the General Surgery Department.

\section{Statistical Methods}

Variables are described by the arithmetic mean as a measure of the central tendency, that is, by standard deviation as a measure of variability. The quality indicators are summarized expressed by the total number of patients with a particular event in the General Surgery Department for the eleven months of 2017. ARIMAX or MARIMAX, as methods of inferential statistics for the analysis of time series, were implemented. The selected level of statistical significance was 0.05 . Data processing was done in the statistical package SPSS 20, IBM 


\begin{tabular}{|l|r|r|r|r|}
\hline \multicolumn{1}{|c|}{ Quality indicators } & N & Mean & SD & Sum \\
\hline Number of hospitalized patients & 11 & 326.27 & 25.89 & 3,589 \\
\hline Number of deaths & 11 & 17.55 & 6.09 & 193 \\
\hline Total mortality rate (\%) & 11 & 5.40 & 1.96 & - \\
\hline Hospitalized patients under 65 years of age & 11 & 183.82 & 18.38 & 2,022 \\
\hline Number of deaths below 65 years of age & 11 & 2.91 & 2.17 & 32 \\
\hline Death rate of less than 65 years of age (\%) & 11 & 1.62 & 1.20 & - \\
\hline Death rate in the first 48 hours of patients' hospitalization (\%) & 11 & 6.70 & 8.02 & - \\
\hline Hospitalized patients with 65 or more years of age & 11 & 142.45 & 14.56 & 1567 \\
\hline Number of deaths at the age of 65 or more & 11 & 14.64 & 5.46 & 161 \\
\hline Death rate is equal to or more than 65 years of age (\%) & 11 & 10.24 & 3.60 & - \\
\hline Number of hospital days & 11 & $1,771.82$ & 225.97 & 19,490 \\
\hline The rate of hospital days per patient & 11 & 5.45 & 0.68 & - \\
\hline Number of nurse per occupied bed & 11 & 0.75 & 0.11 & - \\
\hline Number of patients in the Intensive Care Unit & 11 & 30.18 & 30.30 & 332 \\
\hline Patients rate in the Intensive Care Unit (\%) & 11 & 9.35 & 9.22 & - \\
\hline Number of re-admissions in the Intensive Care Unit & 11 & 4.64 & $\mathbf{2 . 1 1}$ & $\mathbf{5 1}$ \\
\hline Percentage of re-admissions in the Intensive Care Unit (\%) & 11 & 26.87 & 21.79 & - \\
\hline
\end{tabular}

Statistic, New York.

\section{RESULTS}

The description of the quality indicator in the General Surgery Department at monthly level for the first eleven months in 2017 is presented in Table 2. The total number of hospitalized patients was 3,589, of which 2,022 were under 65 years of age. The total number of deaths was 193, of which 161 belonged to the elderly (age $\geq 65$ years). The total number of hospital days was 19,490. In the Intensive Care Unit (ICU), 332 patients were hospitalized, while 51 of them were receiving ICU again.

By applying the MARIMAX modeling, we have shown that there are two signifi- cant, highly adequate models for the prediction: Number of deaths - Model 1 and Total mortality rate - Model 2 (Table 3 ). The average validity for both models was excellent $\left(\mathrm{R}^{2}\right.$ $=0.928, \mathrm{SE}=0.067)$. The individual model adequacy is shown in Table 4. For the Total mortality rate (Model 2), in October 2017, we identified a significant outlier according to the type of positive additive trend $(\mathrm{B}=1.236, \mathrm{SE}=$ $01.453, \mathrm{t}=2.730, \mathrm{p}=0.034$ ).

\section{DISCUSSION}

Two significant, independent predictors with a constant influenced the number of deaths in the General Surgery Department: 1. Patients rate in the ICU and 2. Death rate is equal to

\begin{tabular}{|c|c|c|c|c|c|c|c|}
\hline Model & \multicolumn{3}{|c|}{ Predictors } & Estimated & SE & $\mathrm{t}$ & $\mathbf{p}$ \\
\hline \multirow{3}{*}{$\begin{array}{l}\text { Number } \\
\text { of deaths }\end{array}$} & Number of deaths & Constant & & 7.132 & 2.273 & 3.137 & 0.016 \\
\hline & \multirow{2}{*}{$\begin{array}{l}\text { Patients rate in the Inten- } \\
\text { sive Care Unit (\%) }\end{array}$} & Delay & & 1 & & & \\
\hline & & Numerator & Lag 0 & -0.176 & 0.062 & -2.852 & 0.025 \\
\hline \multirow[t]{2}{*}{ Model 1} & $\begin{array}{l}\text { Death rate is equal to or } \\
\text { more than } 65 \text { years of age (\%) }\end{array}$ & Numerator & Lag 0 & 1.127 & 0.206 & 5.482 & 0.001 \\
\hline & Total mortality rate (\%) & Constant & & 8.971 & 2.005 & 4.475 & 0.004 \\
\hline \multirow{3}{*}{$\begin{array}{l}\text { Total } \\
\text { mortality } \\
\text { rate (\%) }\end{array}$} & $\begin{array}{l}\text { Hospitalized patients under } \\
65 \text { years of age }\end{array}$ & Numerator & Lag 0 & -0.027 & 0.007 & -3.627 & 0.011 \\
\hline & $\begin{array}{l}\text { Death rate is equal to or } \\
\text { more than } 65 \text { years of age (\%) }\end{array}$ & Numerator & Lag 0 & 0.558 & 0.040 & 13.940 & 0.000 \\
\hline & $\begin{array}{l}\text { The rate of hospital days per } \\
\text { patient }\end{array}$ & Numerator & Lag 0 & -0.830 & 0.201 & -4.132 & 0.006 \\
\hline
\end{tabular}

Table 2. Descriptive statistics for quality indicators in General Surgery Department on monthly level for the period January November 2017. 
Table 4. Parameters of individual adequacy according to the model with the number of predictors and autillers by dependent variables
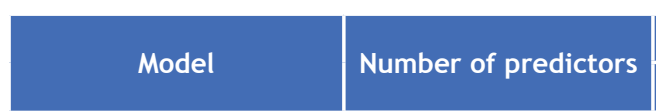

Statistics of adequacy \begin{tabular}{l|l} 
Stationary R2 & R2
\end{tabular}

Number of deaths

Model 1

2

0.881

0.881

Number of outliers

Total mortality rate (\%)

Model 2
3
0.976
0 or more than 65 years of age (\%). If these predictors did not participate in the change of dependent time series, their values would be constant from month to month and would be at the level of their constants shown in Table 3. Thus, the projected average values for the Number of deaths would be 7.132, and for the Total mortality rate $=8.971$ (died on 100 hospitalized patients).

We have shown, however, that with an isolated increase by $1 \%$ in death rates of 65 years and higher, Total mortality rate is increased by about 1.13 times in each current observed month (Table 3). This suggests that the measures for controlling or reducing total mortality rate on the General Surgical Department should certainly be directed to the introduction of preventive procedures to reduce perioperative and postoperative risks in elderly patients, as well as the risk in the entire population of surgical patients. Also, the second predictor of Number of deaths was the Rate of patients who stayed in the ICU, and which was reported as a predictor with a delay effect ("shock effect"). The rate of patients staying at the ICU reflects its impact in the current month by reducing the number of deaths by about $18 \%$ in the next month (Table 3 ). In other words, in our empirical situation on average 7 deceased patients, anesthesiologists have the opportunity to save only one patient. This clearly implies that patients staying at the ICU acts protective to delayed mortality up to two months after surgery or the onset of hospitalization of patients in the General Surgery Department. The percentage of re-admission to the ICU was not a significant predictor for both mortality indicators. Bearing previously said in mind, authors suggest that it is of utmost importance that a certain number of surgically patients with an estimated high preoperative and postoperative mortality risk must stay in the ICU, in order to reanimate and stabilize their health condition.

On the other hand, we have shown that there are three predictors with a constant that generate Total mortality rate, which are:
(1) Hospitalized patients with less than 65 years of age, (2) Death rates at 65 years of age and higher and (3) The rate of hospital days per patient. As the role of Death rates at 65 years of age and higher has already been explained in the previous model, Model 2 has shown that with an isolated reduction in the rate of hospital days per patient for one day per hospitalized patient, the Total mortality rate is reduced by $83 \%$. However, from a medical point of view, it is generally accepted that length of patient stay in hospital is not the cause of patient's mortality, but it is its frequent consequence or is on the path from cause to effect. There is a general tendency at the global level to reduce the duration of hospital stay in healthcare systems in healthcare systems, which is motivated by the reduction of the cost of hotel services in the healthcare system, in order to allocate these funds more appropriately to diagnostics and medical intervention. In our Model 1, we have seen that there is a delay effect in the patient's stay in the ICU in the current month, which is visible only in the next month by reducing the number of deaths, and we consider this model as medically credible in explaining this dependent variable. On the other hand, Model 2 explains the percentage of patients who died in relation to all hospitalized patients. Namely, the patient can be recorded to be released with shorter hospitalization as a living patient in one month (or more), where only the last hospitalization (which is, as a rule, prolonged) will have lethal outcome or will be "transferred" into tertiary level of healthcare without evidencing any possible lethal outcome in our institution. Also, a patient can be translated into a non-surgical department at our facility with lethality records in that department. It is similar to patients who have been hospitalized multiple times; they are recorded as operated in the first and then as non-operated in the second or subsequent hospitalizations. It is considered that the likelihood of the risk of worsening of the medical condition for surgical reasons in the treated patients is close to zero only after two months of surgery. 
We established that there is an October additive trend of the Total mortality rate from previous months which is reflected in the coming months, where the October Total mortality rate, although smaller than the annual average, was still a result of the accumulation tendencies of non-medical activities in order to "satisfy administration". In the months preceding October, such administrative and essentially non-medical activities have just generated a higher patients' mortality rate in General Surgery Department. On the other hand, this effect in Model 1 has been eliminated, which has enabled the demonstration of the protective effect of patients' staying in the ICU. Thus, in Model 2, the protective effect of a short hospital stay of patients at the Total mortality rate, especially in patients with high preoperative, intraoperative and postoperative aviation risk, cannot be "taken for granted". These are patients with a high ASA Physical Status score (anesthesiological score indicating poor preoperative health status of the patient) [10] and/or patients who underwent major surgical procedures with increased aviation risk - low Surgical Apgar Score (SAS) [11-13]. Significant protective effects of patient hospital stay at the mortality rate are legitimate only when these variables are accepted as a variable on the path from cause to result, or when it is understood that it exclusively explains the connection of short-term hospitalization with low mortality risk in patients with oneday surgery or laparoscopic cholecystectomy, "mesh" hernioplasty and other surgeries associated with rapid recovery, whose lethal risk is close to or equal to zero (grade II or grade I by scale of complexity or severity of surgery - intermediate or minor surgery) [13].

Regarding the reduction in mortality under the influence of Number of hospitalized patients under 65 (Table 3) we suggest that additional motivation should be provided for the active working population in order to carry out the necessary surgical treatment on time, particularly interventions that practically do not have lethal risk in the population under 65 years (hernia, gallbladder, gut, etc.). Namely, there is a common trend that the working population in the period of economic crisis avoids to be absent from work due to illness, mainly for financial reasons and / or out of fear of potentially losing the job. For these reasons, these patients "carry" their health problem that does not endanger them vitally, prolong- ing the period of its resolution. In other words, the mentioned indicator actually has the character of a significant socio-economic predictor with a protective effect on the Total mortality rate, so it's pointed out here, although health facilities' opportunities to favor its effects are limited.

\section{Clinical implications and procedures to surgical mortality reducing}

Bearing in mind the above, we suggest that lethality management procedure at the General Surgery Department should be directed towards the recommendations of the principles of good clinical practice in accordance with international guidelines [14]. All these procedures can be divided into preoperative, perioperative and postoperative. First, it is necessary to advise patients and provide them with conditions or help them shower or bathe the body with soap (antimicrobial or non- antimicrobial) or antiseptic, at least the night before the operative day. According to current Guides of Good Clinical Practice, strict recommendations are made for the implementation of this procedure in order to prevent infections of the surgical wound. Secondly, the determination of the ASA score by anesthesiologists is a mandatory clinical procedure for each patient immediately prior to surgery, and in order to adequately prepare the medical procedures that will be carried out jointly by the team of anesthesiologists, intensivists, anesthetists and surgeons perioperatively, intraoperatively and postoperatively, which are indicated in patients with poor preoperative health conditions. In these patients, ASA score is a powerful predictor of elevated early postoperative mortality in the first 48 hours after surgery. Third, the implementation of perioperative antibiotic prophylaxis is a mandatory procedure that prevents infections of surgical wounds, infection of the surgical site, dehiscence of the wound, release of intestinal anastomosis and the emergence of systemic infections [14]. The goal of perioperative antibiotic surgical prophylaxis is to achieve serum and tissue concentrations of antibiotics that exceed their minimum inhibitory concentrations (MICs) for most of the microorganisms, most likely present in the patient at the time of the incision, but also throughout the duration of the surgical procedure. Perioperative antibiotic prophylaxis is performed exclusively by an 
anesthesiologist in the operating room during anesthesia induction. Antibiotics are administered at a single dose up to an hour before the surgical incision, and if necessary at a repeated dose during the surgery, and at least 24 hours postoperatively $[15,16]$.

When it comes to post-surgical procedures for reducing surgical lethality, we consider it is important to continuously identify patients with high risk of postoperative complications including death, through validated clinical methods such as SAS measurement (i.e. identification of patients with SAS $\leq 6$ ). Also, continuous identification of patients with the diagnoses R65, R65.0 and R65.1 according to ICD-10 is necessary, i.e. the determination of patients with Systemic Inflammatory Response Syndrome (SIRS) with monitoring of their Sequential Organ Failure Assessment (SOFA) score by anesthesiologists. The aim of the above measures should be the timely management of patients with SAS $\leq 6$ or diagnosis R65.1 (SIRS score $\geq 2$ and increase of SOFA score $\geq 2$ in the period of $48 \mathrm{~h}$ before infection and up to $24 \mathrm{~h}$ after suspected or proven infection) in the ICU of General Hospital Valjevo [17-19]. Records according to SAS criteria should be performed on a daily basis by surgeons, at least twice a day in patients with major surgical intervention [20]. It is necessary that the records according to SOFA criteria are conducted by anesthesiologists at the call of the surgeon, in case the patient has a SIRS score $\geq 2$. The determination of the SOFA score, as well as the criteria for timely treatment of patients in the ICU, should be carried out in accordance with the valid criteria for the treatment of critically ill patients [21-23].

\section{CONCLUSION}

In order to reduce the Total mortality rate at the Department of General Surgery of Serbian General Hospital Valjevo it is necessary to introduce new quality indicators that are directly related to the clinical procedures that lead to the reduction of adverse outcomes in surgical patients. These indicators should be as follows: the rate of patients bathed at least the night before the surgery, the rate of patients with Surgical Apgar Score lower than 6, the rate of surgical patients undergoing perioperative antibiotic prophylaxis, the rate of patients with diagnoses R65, R65.0 and R65.1 according to the ICD-10, as well as the percentage expres- sion of patients by ASA classes.

\section{REFERENCES}

1. Brennan TA, Leape LL, Laird NM, Hebert L, Localio AR, Lawthers AG, Newhouse JP, Weiler PC, Hiatt $\mathrm{HH}$.. Incidence of adverse events and negligence in hospitalized patients. Results of the Harvard Medical Practice Study I. New England Journal of Medicine 1991; 324:370-6.

2. Wilson RM, Runciman WB, Gibberd RW, Harrison BT, Newby L, Hamilton JD. The Quality in Australian Health Care Study. Medical Journal of Australia 1995; 163:458-71.

3. Leape LL, Brennan TA, Laird N, Lawthers AG, Localio AR, Barnes BA, Hebert L, Newhouse JP, Weiler $P C$, Hiatt $H$. The nature of adverse events in hospitalized patients-results of the Harvard Medical Practice Study II. New England Journal of Medicine 1991; 324:377-84

4. Department of Health Expert Group. United Kingdom Department of Health. An organization with a memory, London, 2000. http://www.dh.gov.uk/ prod_consum_dh/groups/dh_digitalassets/@dh/@ en/documents/digitalasset/dh_4065086.pdf

5. Gawande AA, Thomas EJ, Zinner MJ, Brennan TA.The incidence and nature of surgical adverse events in Colorado and Utah in 1992. Surgery 1999; 126:66-75

6. Kable AK, Gibberd RW, Spigelman AD. Adverse events in surgical patients in Australia. International Journal of Quality in Health Care 2002; 14:269-76.

7. Weiser TG, Regenbogen SE, Thompson KD, Haynes AB, Lipsitz SR, Berry WR, Gawande AA. An estimation of the global volume of surgery. Lancet 2008; $372: 139-44$

8. Ronsmans C, Graham WJ. Maternal mortality: who, where, and why. Lancet 2006; 368:1189-200.

9. Safety WP. WHO Guidelines for Safe Surgery 2009: Safe Surgery Saves Lives. World Health Organization, Switzerland, Geneva, 2009.

10. Hopkins TJ, Raghunathan K, Barbeito A, Cooter M, Stafford-Smith M, Schroeder R, Grichnik K, Gilbert R, Aronson S. Associations between ASA Physical Status and postoperative mortality at $48 \mathrm{~h}$ : a contemporary dataset analysis compared to a historical cohort. Perioper Med (Lond) 2016; 5:29. https://doi.org/10.1186/s13741-016-0054-z

11. Sobol JB. The surgical Apgar score is strongly associated with ICU admission after high-risk intraabdominal surgery. Anesth Analg 2013; 117(2):43846.

12. Regenbogen SE, Ehrenfeld JM, Lipsitz SR, Greenberg CC, Hutter MM, Gawande AA. Utility of the Surgical Apgar Score: Validation in 4119 Patients. Arch Surg 2009; 144(1): 30-6. 
13. Jering MZ, Marolen KN, Shotwell MS, Denton JN, Sandberg WS, Ehrenfeld JM. Combining the ASA Physical Classification System and Continuous Intraoperative Surgical Apgar Score Measurement in Predicting Postoperative Risk. J Med Syst 2015; 39(11):147. DOI https://doi.org/10.1007/s10916015-0332-1

14. Berríos-Torres SI, Umscheid CA, Bratzler DW, Leas B, Stone EC, Kelz RR, Reinke CE, Morgan S, Solomkin JS, Mazuski JE, Dellinger EP. CDC Guideline for the Prevention of Surgical Site Infection, 2017. JAMA Surg 2017; 152(8):784-91.

15. Francetić I, Sardelić S, Bukovski-Simonoski SU, Santini M, Betica-Radić LJ, Belina D, Dobrić I, Dapić T, Erdelez L, Gnjidić Ž, Ivkić M. ISKRA guidelines for antimicrobial prophylaxis in surgery-Croatian national guidelines. Liječnički vjesnik 2010; 132 (78):203-17.

16. Antibiotic Expert Groups. Therapeutic guidelines: antibiotic. Version 15. Surgical Antibiotic Prophylaxis Guideline: Adults. Melbourne: Therapeutic Guidelines Limited, 2014. http://www.watag.org. au/watag/docs/Surgical_Antibiotic_Prophylaxis_ Guideline.pdf

17. Sobol JB, Gershengorn HB, Wunsch H, Li G. The surgical Apgar score is strongly associated with intensive care unit admission after high-risk intraabdominal surgery. Anesth Analg 2013; 117(2):438-46.

18. Regenbogen SE, Ehrenfeld JM, Lipsitz SR, Greenberg CC, Hutter MM, Gawande AA. Utility of the Surgical Apgar Score: Validation in 4119 Patients. Arch Surg 2009; 144(1):30-6.

19. Singer M, Deutschman CS, Seymour CW, Shankar-Hari M, Annane D, Bauer M, Bellomo R, Bernard GR, Chiche JD, Coopersmith CM, Hotchkiss RS. The Third International Consensus Definitions for Sepsis and Septic Shock (Sepsis-3). JAMA 2016; 315 (8):801-10.

20. NICE guideline [NG45]. Routine preoperative tests for elective surgery. 2016, UK. nice.org.uk/ guidance/ng45 https://www.nice.org.uk/guidance/ng45/chapter/Recommendations\#table-1minor-surgery

21. Vincent JL, De Mendonça A, Cantraine F, Moreno R, Takala J, Suter PM, Sprung CL, Colardyn F, Blecher S. Use of the SOFA score to assess the incidence of organ dysfunction/failure in intensive care units: results of a multicenter, prospective study. Working group on "sepsis-related problems" of the European Society of Intensive Care Medicine. Crit Care Med 1998; 26(11):1793-800.

22. Ferreira FL, Bota DP, Bross A, Mélot C, Vincent JL. Serial evaluation of the SOFA score to predict outcome in critically ill patients. JAMA 2001; 286(14):1754-8.

23. Capuzzo M, Valpondi V, Sgarbi A, Bortolazzi S, Pavoni V, Gilli G, Candini G, Gritti G, Alvisi R. Validation of severity scoring systems SAPS II and APACHE II in a single-center population. Intensive
Care Med 2000; 26(12):1779-85. 


\section{Smanjenje mortaliteta na Odeljenju opšte hirurgije u Opštoj bolnici Valjevo}

Mira H. Vuković ${ }^{1}$, Vladan R. Ilić ${ }^{2}$

${ }^{1}$ Opšta bolnica Valjevo, Centar za edukaciju, Valjevo, Srbija

${ }^{2}$ Opšta bolnica Valjevo, Odeljenje za intrahospitalne infekcije, Valjevo, Srbija

\section{KRATAK SADRŽAJ}

Uvod: Bezbednost hirurških procedura pojavila se kao značajan globalni problem javnog zdravstva.

Cilj: U ovoj studiji urađena je procena letaliteta u populaciji pacijenata opšte hirurgije i predložene su medicinske za prevenciju neželjenih događaja koje uključuju i smrt.

Metodologija: Sprovedena je studija vremenskih serija nad rutinski praćenim indikatorima kvaliteta u periodu od Januara do Novembra 2017., sa posebnim osvrtom na broj umrlih i stopu ukupnog letaliteta na Odeljenju Opšte Hirurgije $(\mathrm{OOH})$ Opšte bolnice Valjevo, Srbija.

Rezultati: Hospitalizovani pacijenti stariji od 65 godina i prolongirana hospltalizacija hirurških pacijenata pozitivno su korelisala sa letalitetom na $\mathrm{OOH}$. Kratkotrajni boravak pacijenata u Jedinici intenzivnog lečenja Opšte bolnice Valjevo, značajno je smanjivao stopu ukupnog letaliteta kod pacijenata na $\mathrm{OOH}$.

Zaključak: Neophodno je uvesti rutinski monitoring novih indikatora kvaliteta koji su direktno povezani sa kliničkim procedurama koje dovode do smanjenja mortaliteta kod pacijenata opšte hirurgije.

Ključne reči: stopa mortaliteta, indikatori kvaliteta, opšta hirurgija 